\title{
PEMBERIAN ASI EKSLUSIF, SUPLEMEN VITAMIN A DAN ASUPAN SENG DENGAN RISIKO KEJADIAN PNEUMONIA PADA ANAK BALITA DI PUSKESMAS PUUWATU KECAMATAN PUUWATU KOTA KENDARI
}

\author{
Rita Irma, Sunaryo, Toruntju S. Akbar \\ Jurusan Gizi Poltekkes Kemenkes Kendari
}

\begin{abstract}
Pneumonia is the leading cause of death in children. Many factors can influence the increased incidence of pneumonia in young children, Among them are age, sex, nutritional status, low birth weight, immunization status, Exclusive breastfeeding, and vitamin A. This study aims to determine the relationship of exclusive breastfeeding, supplements vitamin A, and zinc intake with the incidence of pneumonia in children under five in sub-district Puskesmas Puuwatu Kendari. This study uses a casecontrol design. Take place at sub-district Puskesmas Puuwatu Kendari. A sample of 32 samples taken using $\mathrm{P}=$ prevalence of LBW infants $(0.092 \%), \mathrm{d}=$ absolute precision $(10 \%), \mathrm{Z}=$ confidence interval $(95 \%=1.96)$. Taken with accidental sampling technique, and performed on samples Matching namely age, where the age of the sample of cases and controls were age 1 to 5 years. Data analysis was conducted to see the value Odds Ratio $(\mathrm{OR})$, Odds Ratio $(\mathrm{OR})=\mathrm{ad} / \mathrm{bc}$ with confidence interval $(\mathrm{CI})=$ 95\%. The results showed that young children who are not breastfed Exclusive 3.4 times greater risk of pneumonia compared with exclusive breastfeeding of children under five, which marked the value of $\mathrm{OR}=3.40$. Infants and children who do not complete vitamin A supplementation 2.4 times greater risk of developing pneumonia than children under five who complete vitamin A supplementation, which marked the value of $\mathrm{OR}=2.49$. Infants and children who lack their zinc intake were 2.4 times greater risk of pneumonia compared with toddlers sufficient intake of tin, which is marked with $\mathrm{OR}=2.43$. This study concluded that children who are not breastfed Exclusive have an increased risk of pneumonia. Supplementation with vitamin A complete and sufficient zinc intake in children under five among children could reduce the incidence of pneumonia.
\end{abstract}

\section{Keyword: Exclusive breast feeding, Supplements Vitamin A, Zinc intake, Pneumonia}

\section{PENDAHULUAN}

Pneumonia merupakan masalah kesehatan dunia karena angka kematiannya tinggi, tidak saja di negara berkembang tetapi juga di negara maju seperti Amerika Serikat, Kanada, dan negara-negara Eropa. Di Amerika Serikat misalnya terdapat dua juta sampai tiga juta kasus pneumonia per tahun dengan jumlah angka kematian rata-rata 45.000 orang (Misnadiarly, 2008) dalam (Hartati, Nurhaeni, \& Gayatri, 2012).

Period prevalence pneumonia yang tinggi terjadi pada kelompok umur $1-4$ tahun (RISKESDAS, 2013). Insidensi pneumonia dinegara berkembang pada anak balita sebesar 0,28 episode/anak/tahun, sedangkan di negara maju 0,05 episode/anak/tahun. Diperkirakan terdapat 155 juta kejadian baru pneumonia pada anak balita tiap tahunnya, $3-5$ dan sebanyak 7 - 13\% menderita pneumonia berat yang dapat mengancam jiwa dan membutuhkan perawatan di rumah sakit.
The United Nation's Millennium Development Goals (MDGs) ke-4 menyatakan bahwa angka kematian balita harus diturunkan sebanyak 2/3-nya dari tahun 1990 sampai tahun 2015, termasuk menurunkan angka kematian karena pneumonia, namun penurunan angka kematian ini tampaknya masih jauh dari target. Berdasarkan penelitian Bryce dkk. tahun 2000 sampai 2003 didapatkan 10,6 juta anak balita meninggal setiap tahun, dan penyebab utama kematian tersebut adalah pneumonia, yaitu sebesar 19\%. Di Indonesia, angka kematian pneumonia pada balita diperkirakan mencapai 21\% (Unicef, 2006 dalam (Hartati et al., 2012).

Banyak faktor yang dapat berpengaruh terhadap meningkatnya kejadian pneumonia pada balita, baik faktor sosial ekonomi, faktor nutrisi, faktor lingkungan serta riwayat penyakit penyerta (Wonodi et al., 2012). Sedangkan Greenberg, Leibovitz, 2005 dan Depkes RI, 2000, dalam (Rachmawati, 2013) menyatakan faktor risiko intrinsik yang berhubungan dengan 
kejadian pneumonia terbagi atas dua kelompok besar yaitu faktor instrinsik dan faktor ekstrinsik. Faktor instrinsik meliputi umur, jenis kelamin, status gizi, berat badan lahir rendah, status imunisasi, pemberian ASI, dan pemberian vitamin A.

Didapatkan $76,2 \%$ anak yang menderita defisiensi seng dan atau vitamin A mengalami ISPA. Kelompok tersebut berisiko dua kali lebih besar untuk mendapatkan penyakit ISPA dibandingkan dengan seseorang yang tidak mengalami defisiensi seng dan vitamin A. (Fedriyansyah, Nazir, Theodorus, \& Husin, 2010).

Metabolisme vitamin A juga dibantu oleh adanya mineral mikro seperti seng (Zn). Zink berperan penting sebagai mediasi imun non spesifik seperti neutrofil dan sel NK dan imun non spesifik seperti keseimbangan sel Th. Defesiensi zink sebesar $100 \mathrm{mg}$ menjadi salah satu penentu utama pneumonia (Brunt \& Coleman, 2011).

Air susu ibu mengandung zat gizi yang dibutuhkan bayi dan zat kekebalan tubuh yang dapat membantu melawan infeksi (Irianto, 2014). Berdasarkan penelitian-penelitian oleh para ahli bahwa bayi yang diberi ASI lebih kuat dan akan terhindar dari kejadian penyakit asma, pneumonia, diare, infeksi telinga, alergi, kanker anak, diabetes, radang usus buntu dan obesitas (Nirwana, 2014).

Di Sulawesi Tenggara rata-rata kejadian Pneumonia pada balita sebesar 29\%, sedangkan kota Kendari menempati urutan ke-3 setelah kota Bau-Bau dan Konawe Selatan, yaitu sebesar 3,5\%. Dari 10 Penyakit terbesar yang terjadi di Puskesmas Puuwatu diantaranya Pneumonia (ISPA) menduduki urutan pertama, dan selanjutnya penyakit susunan saraf, penyakit mata, Diare, penyakit kulit, hipertensi, radang sendi, Penyakit lain pada Saluran Pernafasan, penyakit usus, dan penyakit kulit infeksi. Penderita ISPA Pada tahun 2010 sebanyak 6060 kasus anak balita yang menderita ISPA dan pada tahun 2011 sebanyak 1581 kasus anak balita yang menderita ISPA, sedangkan data untuk tahun 2012 sebanyak 7581 kasus ISPA dan tahun 2013 sebanyak 968 kasus.

Tujuan penelitian adalah untuk mengetahui hubungan tentang pemberian ASI Eksklusif, suplemen vitamin A, dan asupan Seng dengan kejadian Pneumonia pada anak balita di Puskesmas Puuwatu Kecamatan Puuwatu Kota Kendari.

\section{METODE \\ Jenis Penelitian}

Penelitian ini menggunakan jenis penelitian Deskriptif Analitik dengan pendekatan kasus kontrol.

\section{Lokasi dan Waktu Penelitian}

Penelitian dilakukan di Puskesmas Puuwatu Kecamatan Puuwatu Kota Kendari pada bulan Juli hingga September 2013.

\section{Populasi dan Sampel}

Populasi adalah seluruh anak balita yang berkunjung di Puskesmas Puuwatu Kecamatan Puuwatu Kota Kendari pada tahun 2013 yaitu pada bulan Januari sampai Juni sebanyak 968 kasus. Sampel adalah sebagian dari keseluruhan obyek yang diteliti dan dianggap mewakili seluruh populasi anak balita yang kasus dan kontrol di Puskesmas Puuwatu yaitu masing-masing sebanyak 32 sampel yang diambil dengan menggunakan nilai $\mathrm{P}=$ prevalensi bayi $\operatorname{BBLR}(0,092 \%), \mathrm{d}=$ presisi mutlak (10\%), $\mathrm{Z}=$ derajat kepercayaan $(95 \%=1,96)$.

Sampel diambil dengan teknik accidental sampling, dimana pengambilan sampel diambil dari responden atau kasus yang kebetulan berobat di Puskesmas Puuwatu. Pada penelitian ini dilakukan matching pada sampel yaitu umur, dimana umur pada sampel kasus dan kontrol adalah umur 1 sampai 5 tahun.

\section{Teknik Pengumpulan Data}

Data primer yaitu karakteristik keluarga meliputi, jenis kelamin, jumlah anggota keluarga, pekerjaan dan pendidikan kedua orang tua, dikumpulkan melalui wawancara langsung terhadap responden dengan menggunakan kuesioner. ASI Ekslusif, suplemen vitamin A dan asupan Seng dikumpulkan melalui wawancara langsung menggunakan lembar kuesioner berupa formulir SQ-FFQ (Semi Quantitatif Food Frequency Quesioner) untuk melihat asupan kebiasaan makan anak.

Data sekunder adalah data yang diambil dari instansi terkait yang berhubungan dengan penelitian, meliputi letak geografis dan sarana prasarana Puskesmas Puuwatu.

\section{Analisis Data}

Analisis data dilakukan uji Odds Ratio (OR), Odds Ratio $(O R)=\mathrm{ad} / \mathrm{bc}$ dengan convidence interval $(\mathrm{CI})=95 \%$. Dikatakan bermakna jika 
nilai 1 tidak diantara batas atas dan batas bawah CI dan nilai batas bawah harus lebih dari 1 atau hubungan dikatakan bermakna apabila nilai Lower Limit dan Upper Limit tidak mencakup nilai 1. Analisis Bivariat dilakukan untuk pengujian Hipotesis dengan batas kemaknaan yang digunakan adalah 0,05 dengan $\alpha=1,96$.
HASIL PENELITIAN

Jenis Kelamin dan Umur

Sampel terdiri dari 64 orang, yang terbagi dalam 2 kelompok yakni kasus dan kontrol. Masing-masing kelompok berjumlah 32 orang. Adapun karakteristik sampel dapat dilihat pada tabel 1 .

Tabel 1. Distribusi Sampel berdasarkan Jenis Kelamin dan Umur

\begin{tabular}{lcccc}
\hline & \multicolumn{5}{c}{ Kelompok } \\
\cline { 2 - 5 } Karakteristik & \multicolumn{3}{c}{ Kasus } & \multicolumn{3}{c}{ Kontrol } \\
\cline { 2 - 5 } & & n & n & \% \\
\hline Jenis Kelamin & 13 & 41 & 17 & 53 \\
$\quad$ Perempuan & 19 & 59 & 15 & 47 \\
$\quad$ Laki-laki & & & & \\
Kelompok Umur (Tahun) & 19 & 59 & 13 & 41 \\
$1-3$ & 13 & 41 & 19 & 59 \\
$4-5$ & & & &
\end{tabular}

Berdasarkan tabel 1 diketahui bahwa dari 64 anak balita yang terpilih menjadi sampel diketahui sebesar 19 (59\%) berjenis kelamin laki-laki. Adapun umur sampel diketahui sebesar 19 (59\%) memiliki umur antara $1-3$ tahun dan umur sampel kontrol sebesar 19 $(59 \%)$ berkisar pada umur $4-5$ tahun.
Analisis Hubungan Masing-Masing Variabel Hasil analisis uji statistik terhadap hubungan pemberian ASI Ekslusif dengan kejadian pneumonia pada anak balita dapat dilihat pada tabel 2.

Tabel 2. Distribusi Sampel berdasarkan Hubungan Pemberian ASI Ekslusif, Kapsul Vitamin A dan Asupan Seng dengan Kejadian Pneumonia/ISPA

\begin{tabular}{|c|c|c|c|c|c|}
\hline \multirow{3}{*}{ Variabel } & \multicolumn{4}{|c|}{ Kelompok } & \multirow{3}{*}{$\begin{array}{c}\text { OR } \\
\text { CI 95\% }\end{array}$} \\
\hline & \multicolumn{2}{|c|}{ Kasus } & \multicolumn{2}{|c|}{ Kontrol } & \\
\hline & $\mathbf{n}$ & $\%$ & $\mathbf{n}$ & $\%$ & \\
\hline ASI Ekslusif & & & & & \\
\hline Risiko & 24 & 75 & 15 & 47 & $\begin{aligned} 5,40 \\
1,17\end{aligned}$ \\
\hline Tidak Berisiko & 8 & 25 & 17 & 53 & $1,17-9,00$ \\
\hline Kapsul Vitamin A & & & & & \\
\hline Risiko & 17 & 53 & 10 & 31 & 2,49 \\
\hline Tidak Berisiko & 15 & 47 & 22 & 69 & \\
\hline Asupan Seng & & & & & \\
\hline Risiko & 20 & 62 & 13 & 41 & $089-665$ \\
\hline Tidak Berisiko & 12 & 38 & 19 & 59 & \\
\hline
\end{tabular}

Tabel 2 menunjukkan bahwa bahwa dari 32 sampel pada kelompok kasus, sebagian besar yaitu $24(75 \%)$ termasuk dalam kelompok risiko (tidak diberi ASI Eksklusif) sebaliknya dari 32 sampel pada kelompok kontrol sebesar $17(53 \%)$ tidak berisiko (memberikan ASI Ekslusif). Hasil Analisa statistik didapatkan nilai $\mathrm{OR}=3,40$ dengan nilai upper limit $=9,80$ dan nilai lower limit=1,17. Hal ini menunjukkan bahwa anak balita yang tidak diberi ASI Ekslusif memiliki risiko terkena Pneumonia/ISPA 3,40 kali lebih besar dibandingkan dengan anak balita yang ASI Ekslusif. Adapun Pemberian kapsul vitamin A, sebagian besar yaitu 17 (53\%) termasuk dalam kelompok risiko (tidak lengkap vitamin 
A) sebaliknya dari 32 sampel pada kelompok kontrol sebesar 22 (69\%) tidak berisiko (memberikan vitamin A secara lengkap). Hasil analisa statistik didapatkan nilai $\mathrm{OR}=2,49$ dengan nilai upper limit $=6,91$ dan nilai lower limit $=0,89$, diketahui hasil nilai lower limit $<1$. Ini berarti pemberian vitamin A merupakan faktor proteksi atau dengan kata lain anak balita yang lengkap pemberian kapsul vitamin A dapat mengurangi terjadinya penyakit Pneumonia 0,89 kali dibandingkan anak balita yang tidak lengkap pemberian kapsul vitamin A.

Pada asupan Seng sebagian besar yaitu 20 (62\%) memiliki asupan Seng dalam kategori risiko (rendah asupan Seng) dan dari 32 kelompok kontrol sebesar 19 (59\%) memiliki asupan Seng dengan kategori tidak berisiko (cukup asupan Seng). Hasil analisa statistik didapatkan nilai $\mathrm{OR}=2,43$ dengan nilai upper limit $=6,65$ dan nilai lower limit $=0,89$, diketahui hasil lower limit $<1$. Ini berarti asupan Seng merupakan faktor proteksi atau dengan kata lain anak balita yang cukup asupan Sengnya dapat mengurangi kejadian penyakit Pneumonia 0,89 kali dibandingkan anak balita yang kurang asupan Sengnya.

\section{PEMBAHASAN}

\section{Hubungan Pemberian ASI Ekslusif dengan Kejadian Pneumonia}

Hasil penelitian diketahui ada hubungan pemberian ASI Ekslusif dengan kejadian Pneumonia pada anak balita di Puskesmas Puuwatu Kota Kendari. Hasil penelitian menunjukan bahwa anak balita yang tidak ASI Ekslusif 3,40 kali lebih besar berisiko terkena Pneumonia dibandingkan anak yang ASI Ekslusif. Penelitian ini sejalan dengan penelitian (Choyron, Raharjo, \& Werdani, 2015) yang menunjukkan ada hubungan pemberian ASI eksklusif dengan kejadian pneumonia di wilayah kerja Puskesmas Pedan Klaten dengan nilai estimasi faktor risiko diperoleh OR sebesar 3,095 sehingga dapat diartikan bahwa balita yang tidak mendapatkan ASI eksklusif mempunyai risiko terkena pneumonia sebesar 3,095 kali dibandingkan balita yang mendapatkan ASI eksklusif.

Secara teori telah diketahui bahwa kandungan dalam ASI yang diminum bayi selama pemberian ASI eksklusif sudah mencukupi kebutuhan bayi dan sesuai kesehatan bayi. Air susu ibu mengandung protein, lemak, gula, dan kalsium dengan kadar yang tepat. Air susu ibu juga mengandung zatzat yang disebut antibodi, yang dapat melindungi bayi dari serangan penyakit selama ibu menyusuinya, dan beberapa waktu sesudah itu. Bayi yang senantiasa mengkonsumsi air susu ibu jarang mengalami salesma dan infeksi saluran pernafasan bagian atas pada tahun pertama kelahiran, jika dibandingkan dengan bayi yang tidak mengkonsumsinya. Pertumbuhan dan perkembangan bayi pun berlangsung dengan baik berkat air susu ibu (Prasetyono, 2012).

Penelitian (Kristjana et al., 2014) menunjukkan bayi yang diberi ASI sampai 4 bulan memiliki imun lebih besar dari pada bayi yang tidak diberi ASI. Antibodi IgA pada ASI dapat melindungi bayi terhadap infeksi dengan menetralisir pathogen di permukaan mukosa. Menurut (Nirwana, 2014) salah satu faktor risiko pneumonia yaitu tidak mendapat ASI eksklusif. ASI telah terbukti akan membuat bayi menjadi lebih kuat dan dapat terhindar dari serangan berbagai penyakit, salah satunya yaitu pneumonia

\section{Hubungan Pemberian Suplemen Vitamin A dengan Kejadian Pneumonia}

Hasil penelitian ini menunjukkan bahwa anak balita yang lengkap pemberian kapsul vitamin A dapat mengurangi terjadinya penyakit pneumonia di Puskesmas Puuwatu Kota Kendari. Hasil penelitian ini sejalan dengan penelitian (Fatimah, Sukarsa, \& Made Susilawati, 2015) yang menunjukkan bahwa variabel-variabel yang berpengaruh signifikan terhadap data risiko penyakit pneumonia pada balita di Provinsi Jawa Timur tahun 2012 adalah persentase berat bayi lahir rendah, persentase balita yang mendapatkan imunisasi campak dan persentase balita yang mendapatkan vitamin $\mathrm{A}$.

Vitamin A menjadi faktor penentu dalam proses diferensiasi sel, terutama sel goblet yang dapat mengeluarkan mukus. Mukus melindungi sel-sel epitel dari serbuan mikroorganisme dan partikel lain yang berbahaya. Kekurangan vitamin A menghalangi fungsi sel-sel kelenjar yang mengeluarkan mukus dan digantikan oleh sel epitel bersisik dan kering. Membran mukosa tidak dapat lagi mengeluarkan cairan mukus dengan sempurna sehingga mudah terserang bakteri (Keperien, Bastian, Gunther) dalam (Nurnajiah, Rusdi, \& Desmawati, 2016). 
Defisiensi vitamin A merupakan salah satu faktor yang mempengaruhi kejadian ISPA pada balita terutama terhadap pneumonia. Kekurangan vitamin A akan menyebabkan keratinisasi mukosa saluran pernapasan dan penurunan fungsi cilia serta sekresi mukus pada sel epitel saluran pernapasan sehingga akan menyebabkan tubuh terkena infeksi (WHO, 2010).

\section{Hubungan Asupan Seng dengan Kejadian Pneumonia}

Hasil penelitian ini menunjukkann bahwa anak balita yang cukup asupan Sengnya dapat mengurangi terjadinya penyakit pneumonia di Puskesmas Puuwatu Kota Kendari. Hasil penelitian ini sejalan dengan penelitian Bhutta, Black dan Brown (1999) dalam (Sidiartha, Suandi, \& Subanada, 2012) yang menunjukkan bahwa suplementasi zinc dapat mencegah insidens pnemonia dan diare persisten pada anak yang berada di daerah endemis defisiensi zinc. Bhandari dkk, (2002) dalam (Fedriyansyah et al., 2010) juga melaporkan pemberian suplementasi seng pada anak prasekolah di Dakshinpur iNew Delhi mengurangi kejadian pneumonia dan ISPA.

Defisiensi zinc dapat menurunkan kemampuan sistem imunitas tubuh, seperti imunitas seluler dan imunitas humoral sehingga rentan terhadap infeksi. Defisiensi zinc juga menyebabkan kerusakan jaringan tubuh termasuk jaringan paru (Sidiartha et al., 2012). Mikronutrien zinc terbukti berperan sebagai imunomodulator dan dapat mempertahankan integritas sistem imun (Shankar, Prasad, 1998) dalam (Sidiartha et al., 2012). Defisiensi seng juga menyebabkan rendahnya kadar vitamin A yang menyebabkan terganggunya peran vitamin A dalam sistem kekebalan tubuh untuk deferensiasi limfosit $\mathrm{T}$ dan limfosit $\mathrm{B}$, penghambatan apoptosis, serta dapat mempertahankan integritas dan fungsi permukaan mukosa (Shankar, \& Prasad, 1998 dalam (Fedriyansyah et al., 2010).

\section{KESIMPULAN}

Terdapat $24(75 \%)$ pada sampel kasus termasuk dalam kategori risiko atau tidak mendapatkan ASI Ekslusif, 22 (69\%) pada sampel kontrol termasuk dalam kategori tidak berisiko atau lengkap dalam pemberian kapsul vitamin A sesuai umur, 20 (62\%) pada sampel kasus termasuk dalam kategori risiko atau kurang terhadap asupan Sengnya.
Ada hubungan antara pemberian ASI Ekslusif dengan kejadian Pneumonia pada anak balita $(\mathrm{OR}=3,40)$ dan (LL>1; UL>1), dimana diketahui anak yang tidak ASI Ekslusif memiliki risiko 3,40 kali terkena pneumonia di Puskesmas Puuwatu Kecamatan Puuwatu, Pemberian suplemen Vitamin A yang lengkap pada anak balita dapat mengurangi kejadian Pneumonia di Puskesmas Puuwatu Kecamatan Puuwatu, dimana diketahui hasil uji statistik menunjukkan $(\mathrm{OR}=2,49)$ dan $\quad(\mathrm{LL}<1$ dan UL>1), Asupan Seng yang cukup pada anak balita dapat mengurangi kejadian Pneumonia di Puskesmas Puuwatu Kecamatan Puuwatu, dimana diketahui hasil uji statistik menunjukkan $(\mathrm{OR}=2,43)$ dan (LL $<1$; UL $>1)$.

Bagi pihak Puskesmas perlu melakukan kegiatan dalam upaya peningkatan pengetahuan dan pemahaman kepada keluarga khususnya ibu tentang pentingnya pemberian ASI Ekslusif dan pola makan yang cukup melalui penyuluhan atau pun konsultasi. Perlu dilakukan penelitian lebih lanjut tentang variabel asupan Seng, dimana melakukan uji laboratorium terhadap kandungan Seng dalam darah, sehingga didapat jumlah yang akurat ataupun ketersedian mineral Seng dalam tubuh, yang kaitannya terhadap imunitas tubuh dalam mencegah penyakit infeksi khususnya pneumonia.

\section{DAFTAR PUSTAKA}

Brunt, \& Coleman. (2011). Immune Disease and Children. Uruguay: Amalia Laborde MD.

Choyron, V. A. G., Raharjo, B., \& Werdani, K. E. (2015). Hubungan Pemberian ASI Ekslusif dengan Kejadian Pneumonia pada Balita di Wilayah Kerja Puskesmas Pedan Klaten. Jurnal Kesehatan Masyarakat FIK UMS, 3(1), 1-9.

Fatimah, E. N., Sukarsa, I. K. G., \& Made Susilawati. (2015). Pemodelan Risiko Penyakit Pneumonia pada Balita di Provinsi Jawa Timur dengan Pendekatan Geographically Weihted Logistic Regression. E-Jurnal Matematika, 4(2), 31-36.

Fedriyansyah, Nazir, H., Theodorus, \& Husin, S. (2010). Hubungan Kadar Seng dan vitamin A dengan Kejadian ISPA dan Diare pada Anak. Sari Pediatri, 12(4), 241-246.

Hartati, S., Nurhaeni, N., \& Gayatri, D. (2012). Faktor Risiko Terjadinya Pneumoniapada Anak Balita. Jurnal Keperawatan 
Indoensia, 15(1), 1.

Irianto, K. (2014). Ilmu Kesehatan Anak. Bandung: Alfabeta.

Kristjana, Jenifer, Noel, Dorothy, Elizabeth, Dalton, \& Grace. (2014). Breastfeeding is Associated with Decreased Pneumonia Incidence among HIV-exposed, uninfectedKenyan Infants. NIH Public Access Author Manuscript, 27(17), 2808-2815.

Nirwana. (2014). ASI \& Susu Formula Kandungan dan Manfaat ASI dan Susu Formula. Yogyakarta: Nuha Medika.

Nurnajiah, M., Rusdi, \& Desmawati. (2016). Hubungan Status Gizi dengan Derajat Pneumonia pada Balita di RS.Dr.M. Djamil Padang. Jurnal Kesehatan Andalas, 5(1), 250-255.

Prasetyono, S. (2012). Buku Pintar ASI Eksklusif. Jogjakarta: DIVA Press.

Rachmawati, D. A. (2013). Faktor Risiko yang berhubungan dengan Kejadian Pneumonia pada Balita Umur 12-48
Bulan di Wilayah KerjaPuskesmas Mijen Kota Semarang. Jurnal Kesehatan Masyarakat, 2(1).

RISKESDAS. (2013). Riset Kesehatan Dasar. Penelitian, Badan Pengembangan. Jakarta: Balitbangkes Kemenkes RI.

Sidiartha, I. G. L., Suandi, I. K. G., \& Subanada, I. B. (2012). Efikasi Suplementasi Zinc sebagai Terapi Tambahan Pasien Pneumonia Usia 6-60 Bulan. Jurnal Ilmiah Kedokteran, 43(1), 9-14.

WHO. (2010). Penanganan ISPA pada Anak di Rumah Sakit Kecil Negara Berkembang. Jakarta: EGC.

Wonodi, M, D. K., Feikin, AN, D., HL, J., DR, M., ... JAG, S. (2012). Evaluation of Risk Factors for Severe Pneumonia in Children: The Pneumonia Etiology Research for Child Health Study. Clinical Infectious Disease, 54(2), 124131. 